\title{
ІННОВАЦІЙНИЙ АСПЕКТ ПРОФЕСІЙНОЇ ПІДГОТОВКИ ПРАВООХОРОНЦІВ У ЗАКЛАДІ ВИЩОЇ ОСВІТИ: ВИМОГИ ДО ВИКЛАДАЧА
}

\author{
Тишакова Л. Т. \\ кандидатка педагогічних наук, доцентка, \\ доиентка кафедри іноземних мов \\ Луганський державний університет внутрішніх справ імені Е. О. Дідоренка \\ вул. Донещька, 1, Сєвєродонецьк, Луганська область, Украӥна \\ orcid.org/0000-0001-9237-2730 \\ tishakova.lt@ukr.net \\ Хайруліна Н. Ф. \\ кандидатка філологічних наук, \\ викладачка кафедри іноземних мов \\ Луганський державний університет внутрішніх справ імені Е. О. Дідоренка \\ вул. Донецька, 1, Сєвєродонеиьк, Луганська область, Україна \\ orcid.org/0000-0003-3983-3627 \\ nailiakhairulina@gmail.com
}

\begin{abstract}
Ключові слова: якості викладача ВНЗ, інновачийна діяльність педагога, інноваційна діяльність правоохоронців, готовність до педагогічної діяльності, інновачійні технологї, професіоналізм, професійна компетентність.
\end{abstract}

Стаття присвячена обгрунтуванню процесу оновлення вимог до викладача закладу вищої освіти та його ролі у професійній підготовці майбутніх правоохоронців у навчальному середовищі університету. Проаналізовано проблему формування полікультурної компетентності майбутнього фахівця, яка пов'язана із формуванням особистості педагога, його загальної культури, педагогічної майстерності.

У публікації визначено, що у педагогіці сукупність професійно-зумовлених вимог до педагога визначається готовністю до педагогічної діяльності. Ознаками готовності викладача закладу вищої освіти до педагогічної діяльності, на нашу думку, є: педагогічна самосвідомість; емоційне позитивне ставлення до суб'єкта (курсанта), об'єкта (педагогічного процесу) і засобу діяльності (виховання та навчання); знання про структуру особистості курсанта, його вікові зміни, цілі й засоби педагогічного впливу в процесі іiі формування та розвитку; педагогічні уміння щодо організації і здійснення навчального та виховного впливів на особистість; прагнення спілкуватися зі слухачами, передаючи їм свої досвід та знання, відповідно до змісту і способів досягнення соціально значущих цілей.

Доведено, що інноваційна діяльність викладача закладу вищої освіти передбачає: впровадження інноваційних технологій навчання, спрямованих на удосконалення цілісного навчально-виховного процесу 3ВО; стимулювання інноваційної, пошукової, творчої професійної діяльності; створення інноваційно-творчої атмосфери взаємодії між учасниками процесу навчання; формування інноваційних здібностей, а саме інноваційного мислення, уяви тощо.

Виявлено, що сучасні освітні процеси у правоохоронній галузі зумовлюють нагальну потребу створення цілісної педагогічної системи, що передбачає оптимальне поєднання традиційних i новаторських підходів педагогів до проблеми формування професійної компетентності майбутніх працівників правоохоронних органів, використання інноваційного досвіду наукових досліджень такої проблеми. Авторами визначено, що сучасна професійна підготовка майбутніх працівників правоохоронних органів має орієнтуватись на перспективи міжнародної співпраці, забезпечення мобільності як науковців, викладачів, так і курсантів у межах глобального освітнього і наукового просторів. 


\title{
INNOVATIVE ASPECT OF PROFESSIONAL TRAINING OF LAW ENFORCEMENT OFFICERS AT HIGHER EDUCATIONAL INSTITUTION: REQUIREMENTS TO A PEDAGOGUE
}

\author{
Tyshakova L. T. \\ Candidate of Pedagogical Sciences, Associate Professor, \\ Associate Professor at the Department of Foreign Languages \\ Luhansk State University of Internal Affairs named after E. O. Didorenko \\ Donetska str., 1, Sievierodonetsk, Luhansk region, Ukraine \\ orcid.org/0000-0001-9237-2730 \\ tishakova.lt@ukr.net \\ Khairulina N. F. \\ Candidate of Philological Sciences, \\ Lecturer at the Department of Foreign Languages \\ Luhansk State University of Internal Affairs named after E. O. Didorenko \\ Donetska str., 1, Sievierodonetsk, Luhansk region, Ukraine \\ orcid.org/0000-0003-3983-3627 \\ nailiakhairulina@gmail.com
}

Key words: HEE pedagogue's qualities, innovative pedagogue's activity, law enforcers' activities, readiness to pedagogical activity, innovative technologies, professionalism, professional competence.
The article is devoted to substantiating the renovation process of the HEE lecturers' demands and their role in professional training of future law enforcement officers in the educational university environment. The problem of the formation of multicultural competence of the future specialist which is connected with the formation of the lecturer's personality, his general culture, pedagogical skills, professional competence has been analyzed.

It is determined that in pedagogics a set of professionally qualified requirements for a lecturer is defined by readiness for pedagogical activity. Signs of readiness for pedagogical activity, in our opinion, can be specified as follows: pedagogical self-awareness; emotionally positive attitude to the subject (student), object (pedagogical process) and means of the activity (education and training); knowledge of the structure of the cadet's personality, his age changes, goals and means of pedagogical influence in the process of his formation and development; pedagogical skills in the organization and implementation of educational and upbringing influences on the personality; the desire to communicate with students passing them their experience and knowledge according to the content and ways to achieve socially significant goals.

It has been proved that the innovative activity of the HEE lecturer provides the introduction of the innovative technologies directed to the perfection of the integral educational process of the higher educational institution; stimulation of the innovative, exploratory, creative professional activity; creating innovative and creative atmosphere of interaction between participants during the teaching process; formation of innovative abilities, namely innovative thinking, imagination, etc.

It has been revealed that modern educational processes in law enforcement necessitate creating an integral pedagogical system, which provides an optimal combination of traditional and innovative pedagogues' approaches to the problem of forming future law enforcement officers' professional competence, the use of innovative research experience. The authors consider that modern professional training of future law enforcement officers should be directed toward international cooperation prospects ensuring the mobility of scientists, pedagogues and cadets within the global educational and scientific space. 
Постановка проблеми. Функціонування системи вищої освіти в Україні визначається змістом, технологіями, нормативами та методами керування. Її розвиток залежить від науково-методичної значущості й обсягу освітніх нововведень, а також від ступеня їхнього поширення, що визначають прогресивні зміни у цій системі.

Накопичений у нашій країні технологічний досвід 3 відновлення й удосконалення педагогічних систем, процесів і методів, а також відкриття й успішне функціонування освітніх навчальних закладів нового типу, закладів вищої освіти спеціального призначення становлять один 3 головних напрямів виходу системи освіти на якісно новий рівень розвитку і створюють сприятливі умови для формування професійної компетентності, технологічних умінь та навичок курсантів/студентів закладів вищої освіти.

Реформування вищої системи освіти потребує радикальних змін у навчально-виховному процесі, використання в інноваційній діяльності викладача вищої школи технологій, методів і засобів навчання, які сприяли б реалізації інтелектуального та духовного потенціалу курсантів. Вони не завжди можуть визначити подібність та відмінність істотних елементів, на перший погляд, різних систем, перенести ті ж самі дії з одного об'єкта на інший, еквівалентно перефразувати, переформулювати умови, завдання, побудувати систему, що має бути ізоморфною до вихідної. Усі зазначені процедури становлять більш широке вміння - уміння моделювати, що пов'язане з аналогією, порівнянням та узагальненням. 3 огляду на це, моделювання $є$ основою пізнавальної активності та самостійності. Моделювання - це техніка, яку постійно використовує викладач під час власної інноваційної діяльності.

Метою нашої розвідки $\epsilon$ аналіз вимог до викладача закладу вищої освіти, аналіз стратегічних завдань, що покладені в основу нової поліфункціональної парадигми. Задля реалізації поставленої мети ставимо перед собою такі завдання: здійснити змістовно-структурне, технологічне та організаційно-дидактичне обгрунтування процесу оновлення вимог до викладача закладу вищої освіти та його ролі у професійній підготовці майбутніх правоохоронців в умовах удосконалення цілісного навчально-виховного процесу; інтегрувати, по-перше, інформаційну та модульну технології, по-друге, педагогічні та суміжні $з$ ними дисципліни, використовуючи модульний принцип побудови з метою створення нової інформаційно-модульної технології, наприклад «Інтегрованого курсу педагогіки вищої школи» для студентів-магістрів спеціальності 062 «Правоохоронна діяльність».

У проведенні дослідження використовувалися такі методи, як: системний і теоретичний аналізи психолого-педагогічної та філософської літератури 3 проблеми дослідження; теоретичне моделювання 3 метою розробки інноваційної моделі професійної компетентності майбутнього викладача 3ВО; порівняльний аналіз програм підготовки майбутніх правоохоронців для визначення теоретико-методологічних основ дослідження тощо.

Різні аспекти професійної підготовки майбутніх фахівців висвітлювали у своїх дослідженнях О. Бандурко, А. Рибачук, С. Шевцов, Г. Яворська та інші. Якість вищої юридичної освіти залежить від забезпечення закладу вищої освіти кваліфікованими кадрами, які мають високий рівень професійної компетентності. «Реалізація основних положень Болонського процесу вимагає змін статусу викладачів та наближення навантаження викладачів до європейських стандартів» [6, с. 92].

О. Узунова, К. Калюга стверджують, що «сучасну юридичну освіту очікує серйозне реформування, метою якого проголошується модернізація освіти, формування такої освітньої моделі, яка була б адекватна сучасним викликам глобалізації та інформаційного суспільства, сучасним вимогам несення служби в лавах МВС України та Збройних сил України» [8, с. 229].

Зокрема, В. Савіцька зауважує, що «одним 3 головних завдань ВН3 на сучасному етапі $\epsilon$ побудова такого процесу навчання, який став би основою формування навчальної і професійної діяльності з підготовки і виховання фахівців i сприяв би підвищенню рівня їхньої культури, розширенню кругозору, умінню творчо ставитися до своєї праці» [5, с. 326].

На думку М. Задояного та I. Оксьома, «навчальні плани не завжди враховують неправову сферу діяльності правника (ділову комунікацію, тактику дій, конструктивний аналіз, моделювання ситуацій тощо) - сфер, що не $є$ суто правовими, але становлять важливу прагматичну складову частину повсякденної активності фахівця у праві» [3, c. 282].

Проблему формування полікультурної компетентності майбутнього фахівця, суміжну із такими педагогічними проблемами, що пов'язані із формуванням особистості педагога, його загальної культури, педагогічної майстерності, готовності до педагогічної діяльності та професійної компетентності, досліджували С. Авхутська, І. Бех, I. Зязюн, Н. Кузьміна та інші.

Виклад основного матеріалу дослідження. Інноватизація навчальної діяльності викладача 3ВО передбачає: впровадження інноваційних технологій навчання, спрямованих на вдосконалення цілісного навчально-виховного процесу закладу вищої освіти; стимулювання інноваційної, пошукової, творчої професійної діяльності; створення 
інноваційно-творчої атмосфери взаємодії між учасниками процесу навчання; формування інноваційних здібностей, а саме інноваційного мислення, уяви тощо. Готовність до інноваційної діяльності у курсантів/студентів доцільно формувати за трьохетапною схемою. Підготовчий етап передбачає здійснення викладачем програмно-цільової та діагностичної функцій. Так, програмно-цільова діяльність викладача передбачає конкретизацію умов, що сприяють формуванню у курсантів/студентів готовності до інноваційної діяльності, уточнення, визначення цієї якості відповідно до спеціалізації майбутнього фахівця. Діагностична функція включає загальний аналіз стану навчально-виховного процесу у закладі вищої освіти, що дає можливість визначити рівень знань за чинною системою навчання.

Основний етап - це цілеспрямована діяльність викладача 3 формування у курсантів/студентів готовності до інноваційної діяльності, що передбачає виконання організаційної, інформаційно-роз'яснювальної, координаційної, стимулюючої й контролюючої функцій. Так, організаційна функція включає розробку програм нових спецкурсів для майбутніх правоохоронців i ï проведення; відновлення програм як зі спеціальних предметів, так і з предметів психолого-педагогічного циклу; ефективну організацію педагогічної практики курсантів. Наприклад, магістрам доцільно прослухати спецкурс із теорії моделей, який може складатися 3 таких тем: «Моделі і моделювання: визначення, класифікація та структура»; «Моделювання та навчання»; «Моделювання як метод педагогічних досліджень»; «Моделювання як засіб формування пізнавальної самостійності»; «Використання моделювання на рівні міжпредметних зв'язків»; «Моделювання та інформаційні технології» тощо. Інформаційно-роз'яснювальна функція передбачає здатність викладача чітко, доступно і лаконічно викладати відновлений програмний матеріал, використовуючи різні методи і засоби навчання; координаційна функція забезпечує погодженість, що має бути в процесі застосування нових програм навчання 3 різних предметів; стимулююча - використання різних форм стимулювання інноваційної діяльності курсантів/студентів як у процесі навчання, так і в ході педагогічної практики; контролююча функція вимагає здійснення контролю за виконанням навчального плану і графіка навчального процесу, а також внесення необхідних коригувань, пов'язаних 3 вирішенням поставлених завдань. Підсумковий етап охоплює аналітичну, оцінну та прогностичну функції. Зміст цього етапу становлять: аналіз результатів навчально-виховного процесу у вищому навчальному закладі, що спрямований на підготовку майбутніх правоохоронців до інно- ваційної професійної діяльності, оцінка ефективності проведеної роботи щодо формування готовності курсантів/студентів до інноваційної діяльності засобами моделювання, а також визначення напрямів діяльності викладача на якісно новому рівні.

Зазначена структурно-функціональна модель реалізується під час здійснення умов, визначених на підготовчому етапі діяльності викладача щодо формування готовності курсантів/студентів до майбутньої професійної інноваційної діяльності. При цьому детермінуються певні форми (що забезпечують теоретичну і практичну підготовку курсантів/студентів 3 моделювання), методи i засоби (моделювання, а також пов'язані 3 ним інформаційно-розвивальні, проблемно-пошукові та творчі завдання), що сприяють досягненню необхідного результату - сформованості готовності викладачів 3ВО до інноваційної педагогічної діяльності на високому рівні.

У педагогіці сукупність професійно зумовлених вимог до педагога визначається готовністю до педагогічної діяльності. Явище готовності $\epsilon$ предметом вивчення як педагогів, так і психологів. Перші акцентують увагу на виявленні факторів і умов дидактичних та виховних засобів, що дають змогу керувати становленням і розвитком готовності. Психологи орієнтуються на встановленні характеру зв'язків і залежності між станом готовності та ефективністю діяльності. 3 одного боку, готовність $є$ особистісною (емоційно-інтелектуальною, вольовою, мотиваційною, що включає інтерес, ставлення до діяльності, почуття відповідальності, упевненість у досягненні успіху, потребу виконання поставлених завдань на високому професійному рівні, керування своїми почуттями, мобілізації сил, подолання невпевненості тощо); з іншого - операційно-технічною, що включає інструментарій педагога (професійні знання, уміння, навички і засоби педагогічного впливу).

Педагогічна самосвідомість є одним із важливих компонентів готовності до діяльності педагога. Людська свідомість, яка виникає в процесі предметно-перетворювальної діяльності, має дві грані, що нерозривно пов'язані. Це усвідомлення всього зовнішнього стосовно суб'єкта і самосвідомість як відображення суб' єктом самого себе. Завдяки свідомості перед особистістю розгортається широкий спектр можливостей розвитку і самовдосконалення. Усвідомлюючи себе, суб'єкт розуміє рівень відповідності своїх особистісних властивостей соціально-моральним, професійним нормам. Наявність педагогічних здібностей є необхідною структурною одиницею професійної готовності. Вирішальними для становлення такої готовності є: педагогічне мислення, уява, спостережливість, рефлексивні здібності. Рефлексивний рівень 
педагогічних здібностей звернений до об'єкта/ суб'єкта педагогічного впливу і спрямований на перцепцію слухачів.

Наступним компонентом готовності до педагогічної діяльності є професійно значущі якості. До них належать: професійна компетентність, яка включає такі поняття, як володіння матеріалом, розвиненість, ерудиція, інформованість, начитаність тощо. Рефлексивна природа керування навчально-виховним процесом пов'язана 3 емпатією, тобто розумінням емоційного стану курсанта, здатністю співпереживати, співчувати йому. Ознаки готовності до педагогічної діяльності можна конкретизувати в такий спосіб: «педагогічна самосвідомість; емоційно-позитивне ставлення до суб'єкта (учня), об'єкта (педагогічного процесу) і засобу діяльності (виховання та навчання); знання про структуру особистості курсанта, його вікові зміни, цілі й засоби педагогічного впливу в процесі іiі формування і розвитку; педагогічні уміння щодо організації і здійснення навчального та виховного впливів на особистість, яка формується; прагнення спілкуватися зі слухачами, передаючи їм свої досвід та знання відповідно до змісту і способів досягнення соціально значущих цілей» [2, с. 192].

Як стверджує вчений Г. М'ясоїд, «розрив між системою підготовки викладачів та вимогами, які до них ставляться, є основною перешкодою до подолання стереотипного мислення та стереотипної поведінки викладачів. Утім, попри перелік зовнішніх і внутрішніх механізмів, які повинні стимулювати викладача до виконання інноваційної професійної діяльності, залишається нез'ясованим, які з функцій викладача закладу вищої освіти $€$ новими, яких спеціальних умінь і навичок він потребує для виконання цих функцій, і якими $є$ пріоритетні напрями модернізації системи професійної підготовки, пере- і самопідготовки викладача на сучасному етапі, щоб відповідати новим вимогам» $[4$, с. 111$]$.
Викладач 3ВО повинен володіти більш широким набором навичок та мати готовність виконувати соціальні ролі, які раніше не враховувалися у системі підготовки педагогічних кадрів. Слід зазначити, що підготовка викладача ЗВО у відповідності до сучасних вимог можлива тільки за умов створення низки внутрішніх та зовнішніх факторів.

Висновки та перспективи подальших досліджень. Вимоги до викладача закладу вищої освіти на сучасному етапі розвитку системи вищої освіти значно збільшилися. Нині викладач вищої школи виконує широкий спектр соціальних ролей. Це i знання предмета, уміння виступати експертом із галузі знань, яку він викладає, бути дослідником, порадником, організатором і виконавцем навчального процесу, представником закладу вищої освіти перед громадою та установами, а також фасилітатором навчальної та дослідницької діяльності курсантів/студентів, членом команди 3 розробки принципово нових курсів і дисциплін, які пропонуються для вибору курсантам/студентам закладу вищої освіти, адміністратором, розробником навчальних проєктів тощо. Викладачеві ЗВО необхідно володіти відповідними навичками та компетенціями, які поки що не прописані в наказах Міністерства освіти і науки України, але наявності яких вимагає сучасна дійсність. Слід також зазначити, що викладацька робота вимагає від педагога здібності оцінювати свою працю у цілому, оцінювати себе як особистість, професіонала, науковця, переходити до оцінки свого професіоналізму, результативності своєї діяльності. Професійна усталеність викладача ЗВО з особливими умовами навчання потребує більш детального дослідження. Знання компонентів ㄲï структури та їх ознак відкриває шляхи для подальшого вдосконалення особистості викладача вищої школи, оскільки саме професійна усталеність дає змогу реалізувати як його педагогічний, так і науковий потенціал у педагогічну майстерність, професіоналізм, творчість.

\section{ЛIТЕРАТУРА}

1. Авхутська С. Полікультурна компетентність як чинник професійного й особистісного зростання майбутнього учителя історії. Проблеми підготовки сучасного вчителя. 2011. Ч. 1. С. 110-111.

2. Євтух М. Актуальні проблеми педагогіки : навчально-методичний посібник для студентів вищих навчальних закладів. Слов’янськ : Маторін Б.І., 2013. 366 с.

3. Задояний М. Сучасні підходи щодо модернізації юридичної освіти в Україні. Публічне право. 2012. № 4(8), С. 276-284.

4. М'ясоїд Г. Сучасні вимоги до викладача вищої школи: огляд тенденцій світової педагогічної практики. Педагогічні науки: теорія, історія, інноваційні технологіï, 2015. № 3(47), С. 111.

5. Савіцька В. Готовність майбутнього соціального працівника до професійної діяльності як запорука iii ефективності. Збірник наукових праць Уманського держсавного педагогічного університету. 2013. Ч. 2. C. 325. URL: http://nbuv.gov.ua/j pdf/znpudpu_2013_2_44.pdf.

6. Світовська Л. Сучасний погляд на підготовку майбутніх юристів до професійної діяльності у пенітенціарній системі в педагогічній теорії. Наукові записки Національного педагогічного університету ім. М.П. Драгоманова. Сер.: Педагогічні та історичні науки. 2014. Вип. 120, С. 127-134. 
7. Сурмін Ю. Методология анализа ситуаций. Киев : Центр инноваций и развития, 1999. 94 с.

8. Узунова О. Проблемні питання вивчення права працівниками міліції та підготовки юристів-професіоналів в органах внутрішніх справ: радянський та сучасний аспекти. Вісник Запорізького національного університету. Сер.: Юридичні науки. 2013.№ 1(2), С. 227. URL: http://nbuv.gov.ua/j pdf/ Vznu_Jur_2013_1(2)_40 pdf.

\section{REFERENCES}

1. Avhutska, S. (2011). Polikulturna kompetentnist yak chynnyk profesijnogo j osobystisnogo zrostannya majbutnogo uchytelya istoriyi. Problemy pidgotovkysuchasnogo vchytelya. Ch.1. S. 110-111 [in Ukrainian].

2. Yevtuh, M. (2013). Aktualni problemy pedagogiky : navch.-metod. posib. dlya stud. vyshh. navch. zakl. Slovyansk : Matorin B.I., 366 s. [in Ukrainian].

3. Zadoyanyj M. (2012). Suchasni pidhody shhodo modernizaciyi yurydychnoyi osvity v Ukrayini. Publichne pravo. No. 4(8), S. 276-284 [in Ukrainian].

4. Myasoyid G. (2015). Suchasni vymogy do vykladacha vyshhoyi shkoly: oglyad tendencij svitovoyi pedagogichnoyi praktyky. Pedagogichni nauky: teoriya, istoriya, innovacijni tehnologiyi. No. 3(47). S. 111 [in Ukrainian].

5. Saviczka, V. (2013). Gotovnist majbutnogo socialnogo pracivnyka do profesijnoyi diyalnosti yak zaporuka yiyi efektyvnosti. Zbirnyk naukovyh pracz Umanskogo derzhavnogo pedagogichnogo universytetu. Ch. 2, S. 325-331. URL: http://nbuv.gov.ua/j pdf/znpudpu_2013_2_44.pdf [in Ukrainian].

6. Svitovska, L. (2014). Suchasnyj poglyad na pidgotovku majbutnih yurystiv do profesijnoyi diyalnosti $\mathrm{u}$ penitenciarnij systemi $\mathrm{v}$ pedagogichnij teoriyi. Naukovi zapysky Nacionalnogo pedagogichnogo universytetu im. M.P. Dragomanova. Ser: Pedagogichni ta istorychni nauky. Vyp. 120, S. 127-134 [in Ukrainian].

7. Surmin, Yu. (1999). Metodologyya analyza sytuacyj. Kiev : Centr ynnovacyj y razvytyya, 94 s. [in Russian].

8. Uzunova, O. (2013). Problemni pytannya vyvchennya prava pracivnykamy miliciyi ta pidgotovky yurystiv-profesionaliv v organah vnutrishnih sprav: radyanskyj ta suchasnyj aspekty. Visnyk Zaporizkogo nacionalnogo universytetu. Ser: Yurydychni nauky. No 1(2), S. 227. URL: http://nbuv.gov.ua/j pdf/Vznu_ Jur_2013_1(2)_40 pdf [in Ukrainian]. 